\title{
Front Matter: Volume 9195
}

, "Front Matter: Volume 9195," Proc. SPIE 9195, Optical System Alignment, Tolerancing, and Verification VIII, 919501 (26 September 2014); doi: 10.1117/12.2085354

EDIE Event: SPIE Optical Engineering + Applications, 2014, San Diego, California, SPIE. United States 


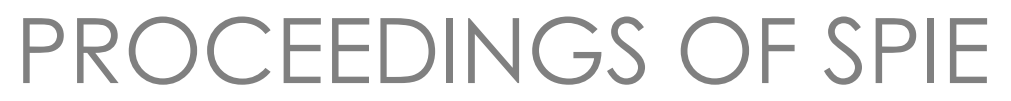

\section{Optical System Alignment, Tolerancing, and Verification VIII}

José Sasián

Richard N. Youngworth

Editors

17-18 August 2014

San Diego, California, United States

Sponsored and Published by

SPIE

Volume 9195

Proceedings of SPIE 0277-786X, V. 9195

SPIE is an international society advancing an interdisciplinary approach to the science and application of light.

Optical System Alignment, Tolerancing, and Verification VIII, edited by José Sasián,

Richard N. Youngworth, Proc. of SPIE Vol. 9195, 919501 · (c) 2014 SPIE

CCC code: $0277-786 X / 14 / \$ 18 \cdot$ doi: $10.1117 / 12.2085354$

Proc. of SPIE Vol. $9195919501-1$ 
The papers included in this volume were part of the technical conference cited on the cover and title page. Papers were selected and subject to review by the editors and conference program committee. Some conference presentations may not be available for publication. The papers published in these proceedings reflect the work and thoughts of the authors and are published herein as submitted. The publisher is not responsible for the validity of the information or for any outcomes resulting from reliance thereon.

Please use the following format to cite material from this book:

Author(s), "Title of Paper," in Optical System Alignment, Tolerancing, and Verification VIII, edited by José Sasián, Richard N. Youngworth, Proceedings of SPIE Vol. 9195 (SPIE, Bellingham, WA, 2014) Article CID Number.

ISSN: 0277-786X

ISBN: 9781628412222

\section{Published by}

\section{SPIE}

P.O. Box 10, Bellingham, Washington 98227-0010 USA

Telephone +1 3606763290 (Pacific Time) · Fax +1 3606471445

SPIE.org

Copyright (C) 2014, Society of Photo-Optical Instrumentation Engineers.

Copying of material in this book for internal or personal use, or for the internal or personal use of specific clients, beyond the fair use provisions granted by the U.S. Copyright Law is authorized by SPIE subject to payment of copying fees. The Transactional Reporting Service base fee for this volume is $\$ 18.00$ per article (or portion thereof), which should be paid directly to the Copyright Clearance Center (CCC), 222 Rosewood Drive, Danvers, MA 01923. Payment may also be made electronically through CCC Online at copyright.com. Other copying for republication, resale, advertising or promotion, or any form of systematic or multiple reproduction of any material in this book is prohibited except with permission in writing from the publisher. The CCC fee code is 0277-786X/14/\$18.00.

Printed in the United States of America.

Publication of record for individual papers is online in the SPIE Digital Library.

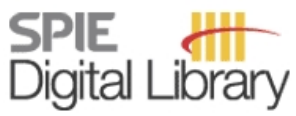

SPIEDigitalLibrary.org

Paper Numbering: Proceedings of SPIE follow an e-First publication model, with papers published first online and then in print and on CD-ROM. Papers are published as they are submitted and meet publication criteria. A unique, consistent, permanent citation identifier (CID) number is assigned to each article at the time of the first publication. Utilization of CIDs allows articles to be fully citable as soon as they are published online, and connects the same identifier to all online, print, and electronic versions of the publication. SPIE uses a six-digit CID article numbering system in which:

- The first four digits correspond to the SPIE volume number.

- The last two digits indicate publication order within the volume using a Base 36 numbering

system employing both numerals and letters. These two-number sets start with 00, 01, 02, 03, 04, 05, 06, 07, 08, 09, 0A, 0B ... 0Z, followed by 10-1Z, 20-2Z, etc.

The CID Number appears on each page of the manuscript. The complete citation is used on the first page, and an abbreviated version on subsequent pages. Numbers in the index correspond to the last two digits of the six-digit CID Number. 


\title{
Contents
}

\author{
$\checkmark \quad$ Authors \\ vii Conference Committee \\ ix Introduction \\ xi Radiance and photon noise: imaging in geometrical optics, physical optics, quantum \\ optics and radiology (Plenary Paper) [9193-200] \\ xxix Optical design for consumer products (Plenary Paper) [9197-201]
}

\section{SESSION 1 OPTICAL DESIGN AND TOLERANCE ANALYSIS I}

919502 Modeling decenter, wedge, and tilt errors in optical tolerance analysis and simulation [9195-1]

919503 Photonic Doppler velocimetry probe designed with stereo imaging [9195-2]

919504 Optical design and tolerancing of an ophthalmological system [9195-3]

919505 Study on decentration-induced optical aberrations in an optical system using Shack Hartmann wavefront sensor [9195-4]

\section{SESSION 2 OPTICAL DESIGN AND TOLERANCE ANALYSIS II}

919506 Tolerancing sub-aperture regions of optical surfaces using circular and elliptical Zernike polynomials [9195-5]

919507 Statistical distributions from lens manufacturing data (Invited Paper) [9195-6]

919508 Tolerances in panoramic lenses (Invited Paper) [9195-7]

919509 Designing null screens type sub-structured Ronchi to test a fast plano-convex aspheric lens [9195-8]

\section{SESSION 3 VERIFICATION FOR OPTICAL SYSTEMS}

9195 OA Analysis methodology for a piezoelectric-driven optical tracker for ground based interferometry [9195-9]

9195 OB Imagery analysis and the need for standards (Invited Paper) [9195-10] 
9195 OE Dual-interferometer for measuring molded lens tilt and decenter [9195-13]

9195 OF Aligning and testing non-null optical system with deflectometry [9195-14]

$91950 \mathrm{Ambient}$ optomechanical alignment and pupil metrology for the flight instruments aboard the James Webb Space Telescope [9195-15]

$9195 \mathrm{OH} \quad$ Integration, alignment, and verification of optical system assembly for FORMOSAT-5 [9195-16]

91950 Aberration analysis and calculation in system of Gaussian beam illuminates lenslet array [9195-17]

POSTER SESSION

9195 OK Analysis of a spaceborne mirror on a main plate with isostatic mounts [9195-19]

9195 OL Dynamic mesh-based analysis of dynamic irradiance characteristics of solar simulator [9195-20]

$91950 \mathrm{M}$ Analysis of target wavefront error for secondary mirror of a spaceborne telescope [9195-21]

9195 OP Dynamic compensation for the lithographic object lens [9195-24] 


\section{Authors}

Numbers in the index correspond to the last two digits of the six-digit citation identifier (CID) article numbering system used in Proceedings of SPIE. The first four digits reflect the volume number. Base 36 numbering is employed for the last two digits and indicates the order of articles within the volume. Numbers start with 00, 01, 02, 03, 04, 05, 06, 07, 08, 09, OA, OB...0Z, followed by 10-12, 20-2Z, etc.

Avendaño-Alejo, Maximino, 09

Barrett, Harrison H., xi

Beaton, Alexander, $0 G$

Burge, James H., OF

Castán Ricaño, Diana, 09

Cata, Brian M., 03

Caucci, Luca, xi

Chan, Chia-Yen, $\mathrm{OH}, \mathrm{OK}, \mathrm{OM}$

Chang, Shenq-Tsong, $\mathrm{OH}, \mathrm{OK}, \mathrm{OM}$

Chen, Chia-Ray, $\mathrm{OH}$

Chen, Ching-Wei, $\mathrm{OH}$

Chen, Zexiang, OP

Clark, James H., III, OA

Coulter, Phillip, OG

Dallaire, Xavier, 08

Daykin, Edward P., 03

Esquibel, David L., 03

Feng, Yun, 0 I

Frogget, Brent C., 03

Ganesan, A. R., 05

Grant, Barbara G., OB

Gregory, Michael K., 07

Gu, Yaxiu, OL

Gum, Jeffery S., OG

Gupta, Anurag, xxix

Hadjimichael, Theodore J., OG

Hayden, Joseph E., OG

Herman, Eric, 02

Holtkamp, David B., 03

$\mathrm{Hsu}$, Ming-Ying, $\mathrm{OH}$

Huang, Chih-Yu, 06

Huang, Po-Han, $\mathrm{OH}$

Huang, Po-Hsuan, $\mathrm{OH}, \mathrm{OK}$

Huang, Run, OF

Huang, Ting-Ming, $\mathrm{OH}, \mathrm{OK}, \mathrm{OM}$

Hui, Mei, Ol

Hummel, Susann, 0G

Hylan, Jason E., OG

Kalikivayi, V., 05

Kannan, K., 05

Kaufman, Morris I., 03, 07

Krishna Kumar, R., 05

Kuhn, William P., OE

Kuo, Ching-Hsiang, $\mathrm{OM}$

Lee, David, OG

Li, Likai, 04

Li, Yanpeng, OL

Liang, Rongguang, 06

Lien, Chun-Chieh, OH, OK
Light, Brandon B., 07

Lin, Wei-Cheng, OM

Lin, Yu-Chuan, OM

Madison, Timothy J., OG

Malone, Robert M., 03, 07

Martin, Thomas, 04

Maszkiewicz, Michael, OG

McGillivray, Kevin D., 03

Mclean, Kyle F., OG

McMann, Joseph, OG

Melf, Markus, OG

Meng, Qinglong, OL

Miner, Linda, OG

Myers, Kyle J., xi

Ohl, Raymond G., IV, OG

Palagi, Martin J., 03

Parks, Robert E., OE

Pazuchanics, Peter, 03

Penado, F. Ernesto, OA

Redman, Kevin, OG

Roedel, Andreas, 0G

Romero, Vincent T., 03

Rübenach, Olaf, 04

Schweiger, Paul, OG

Sieber, Ingo, 04

Sorenson, Danny S., 03

Su, Peng, OF

Su, Tianquan, 0

Te Plate, Maurice, $0 \mathrm{G}$

Thibault, Simon, 08

Wells, Martyn, OG

Wenzel, Greg W., OG

Williams, Patrick K., OG

Xing, Tingwen, OP

Yi, Allen, 04

Young, Jerrod, OG

Youngworth, Richard N., 02, 06

Zhao, Weirui, OF

Zhao, Yuejin, 01

Zhao, Zhu, Ol

Zhou, Ping, 0 I

Zhu, Hongwei, OP 
Proc. of SPIE Vol. $9195919501-6$

Downloaded From: https://www.spiedigitallibrary.org/conference-proceedings-of-spie on 26 Apr 2023 Terms of Use: https://www.spiedigitallibrary.org/terms-of-use 


\section{Conference Committee}

Program Track Chairs

José Sasián, College of Optical Sciences, The University of Arizona (United States)

R. John Koshel, College of Optical Sciences, The University of Arizona

(United States)

Conference Chairs

José Sasián, College of Optical Sciences, The University of Arizona (United States)

Richard N. Youngworth, Riyo LLC (United States)

Conference Program Committee

Matthew B. Dubin, College of Optical Sciences, The University of Arizona (United States)

Jonathan D. Ellis, University of Rochester (United States)

Sen Han, University of Shanghai for Science and Technology (China)

Marco Hanft, Carl Zeiss AG (Germany)

Chao-Wen Liang, National Central University (Taiwan)

Norbert Lindlein, Friedrich-Alexander-Universität Erlangen-Nürnberg (Germany)

Robert M. Malone, National Security Technologies, LLC (United States)

Raymond G. Ohl IV, NASA Goddard Space Flight Center (United States)

Robert E. Parks, Optical Perspectives Group, LLC (United States)

Martha Rosete-Aguilar, Universidad Nacional Autónoma de México (Mexico)

Daniel G. Smith, Nikon Research Corporation of America (United States)

Peng Su, College of Optical Sciences, The University of Arizona (United States)

Yana Z. Williams, Atlas Material Testing Technology (United States)

Session Chairs

1 Optical Design and Tolerance Analysis I

Peng Su, College of Optical Sciences, The University of Arizona (United States)

2 Optical Design and Tolerance Analysis II

Robert M. Malone, National Security Technologies, LLC (United States) 
3 Verification for Optical Systems

Robert E. Parks, Optical Perspectives Group, LLC (United States)

4 Metrology in Alignment, Tolerancing, and Verification

José Sasián, College of Optical Sciences, The University of Arizona (United States) 


\title{
Introduction
}

We never cease to be grateful to the wonderful community that makes this niche specialty conference so memorable. This year, the eighth in the conference series, was certainly no exception to this sentiment. The 2014 Optical System Alignment, Tolerancing, and Verification VIII conference in San Diego was once again excellent. As usual our conference consisted of a day of quality presentations, poster session, and subsequent proceedings articles. We had four sessions involving optical design and tolerance analysis, verification, and alignment of optical systems. We sincerely thank our invited speakers, contributed speakers, poster paper presenters, and the superb community for our success in this conference. The community clearly values this conference and the exchange of ideas it creates.

We must of course thank our program committee for continuing to promote this conference. Finally we thank the volunteers and SPIE staff for providing us the opportunity to cover the subjects of optical system alignment, tolerancing, and verification in a dedicated conference and proceedings volume.

This conference will continue in 2015, which is the International Year of Light. We encourage everyone interested in optical system alignment, tolerancing, and verification to look for the call for papers and to submit your work in early 2015. Please feel free to contact us or anyone on our program committee if you have any questions.

In the meantime, we wish you all the best in your endeavors.

\author{
José Sasián \\ Richard N. Youngworth
}


Proc. of SPIE Vol. $9195919501-10$

Downloaded From: https://www.spiedigitallibrary.org/conference-proceedings-of-spie on 26 Apr 2023 Terms of Use: https://www.spiedigitallibrary.org/terms-of-use 